EETP Vol. 15, 2020, №. 2(56)

ISSN 1896-2327 / e-ISSN 2353-7787

DOI: $10.35765 /$ eetp.2020.1556.07

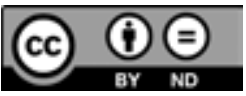

Nadesłano: 1.04.2019

Zaakceptowano: 9.05.2020

Sugerowane cytowanie: Sanecka A. (2020). Rola pamięci i opowieści w kształtowaniu tożsamości i wychowaniu aksjologicznym dziecka. Pedagogiczne refleksje na temat spektaklu Opowieści z niepamięci, „Edukacja Elementarna w Teorii i Praktyce”, vol. 15, nr 2(56), s. 95-108. DOI: $10.35765 /$ eetp.2020.1556.07

\title{
Rola pamięci i opowieści w kształtowaniu tożsamości i wychowaniu aksjologicznym dziecka. Pedagogiczne refleksje na temat spektaklu Opowieści z niepamięci
}

\author{
The Role of Memory and Stories in Shaping a Child's \\ Identity and Axiological Education. Pedagogical \\ Reflections on the Theatre Performance: Stories from \\ Oblivion
}

\footnotetext{
SŁOWA KLUCZE ABSTRAKT

opowieść, Celem artykułu jest prezentacja spektaklu teatralnego dla dzieci Opomitologia, pamięć, wieści z niepamięci jako narzędzia kształtowania tożsamości kulturozapominanie, wej dziecka oraz wprowadzenia najmłodszej widowni w tematykę paprzedstawienie mięci jako kategorii etycznej. W badaniu wykorzystano analizę treści teatralne, tożsamość spektaklu i zinterpretowano go w kontekście filozoficznych rozważań Paula Ricoeura dotyczących opowieści, czasu, pamięci i zapominania. Poszczególne części artykułu dotyczą: pedagogicznej roli pamięci; mitologii słowiańskiej; opowieści jako gatunku narracyjnego; pamięci i zapominania oraz ich społecznych skutków; tożsamości i jej kształtowania; wychowawczych wartości prezentowanego przedstawienia. Opierając się na przekonaniach Ricoeura dotyczących opowieści, pamięci i zapominania, oraz poglądach pedagogicznych Bogusława Milerskiego, stwierdzono, że treść omawianego spektaklu i sposób poruszania w nim wspomnianej tematyki mogą być przykładami wychowania do pamięci oraz uznania opowieści za znaczące narzędzie w procesie kształtowania tożsamości.
} 


\section{KEYWORDS ABSTRACT}

story, mythology, memory, forgetting,

performance, identity

(...) nasza hipoteza równa się (...) uznaniu opowieści za strażnika czasu (...) Paul Ricoeur (2008c: 347)

W ostatecznym rachunku obowiązek pamiętania jako imperatyw sprawiedliwości wchodzi w zakres problematyki moralnej (...)

Paul Ricoeur (2006: 121)

\section{Joanna Cukras-Stelągowska pisze:}

Pamięć powinna stanowić źródło wiedzy o swojej tożsamości zarówno gdy mowa o pamięci jednostkowej, jak i społecznej. Być może to właśnie pedagogika powinna koncentrować się na akcentowaniu wartości społecznego pamiętania i przypominania (...). Pedagogika stawia przecież pytania o wartości, normy, dziedzictwo kulturowe. (...) Ważne staje się budowanie poczucia wspólnoty pamięci, a świadomość historyczna jest nieodzownym elementem współczesnej tożsamości (Cukras-Stelągowska 2016: 8).

To stwierdzenie jest istotne w kontekście przedstawienia Opowieści z niepamięci, którego oś fabularną stanowi próba niedopuszczenia do zatarcia w pamięci ważnego elementu społecznej rzeczywistości i kulturowej tożsamości - mitologii. Pamięć i narracja uczestniczą w tworzeniu tożsamości kulturowej człowieka i wpływają na jego wychowanie moralne. Pamięć, niepamięć, zapominanie, a także narracja, wiążą się z czasem. Na „czasowy charakter ludzkiego doświadczenia”, a także opowieści dzieła narracyjnego, zwraca uwagę Paul Ricoeur pisząc: „Świat przedstawiony każdego 
dzieła narracyjnego jest zawsze czasowym światem (...) czas staje się ludzkim czasem $\mathrm{w}$ tej mierze, w jakiej zostaje narracyjnie wyartykułowany; natomiast opowieść jest znacząca w takim stopniu, w jakim kreśli zarys czasowego doświadczenia" (Ricoeur 2008a: 17). Wyjaśnia też, „że między opowiadaniem historii a czasowym charakterem ludzkiego doświadczenia istnieje współzależność, która nie jest czysto przypadkowa, lecz prezentuje się jako ponadkulturowa konieczność" (Ricouer 2008a: 83). Ponieważ Ricoeur poświęca wiele uwagi pojęciom: opowieść, czas, pamięć, zatem w niniejszym artykule Opowieści z niepamięci zostaną przeanalizowane z punktu widzenia jego poglądów. Analiza taka będzie też sposobem na ukazanie roli opowieści w kształtowaniu tożsamości odbiorcy, wpływaniu na jego postawy etyczne oraz gotowość do przyszłych działań.

\section{Opowieści z niepamięci jako opowieść o roli pamięci i zapominania}

Poznański Teatr Animacji fabułę spektaklu przedstawia następująco:

Na scenę wychodzą aktorzy, by (...) powoli snuć opowieści o potężnych Płanetnikach, szalonych leśnych znachorkach Babach, przebiegłych i niebezpiecznych Jędzach, czy budzącym grozę, tajemniczym Bezkoście. Jednak już na początku legendy pojawia się Kłobuk, cichy leśny duch, którego obecność zawsze zwiastuje nieszczęście. Od tego momentu wszystko idzie nie tak, legendy, zamiast pojawiać się w słowach i szeptach, ożywają! (https://teatranimacji.pl/spektakl/opowiesci-z-niep/).

Kłobuk spełnia życzenie jednego z aktorów i Płanetnik spada na ziemię - jest tak słaby, że nie daje rady wrócić na niebo. Aktorzy szukają więc pomocy u Baby, która choć okazuje się bezradna, daje bohaterom pewne wskazówki i poleca im znalezienie jaja od czarnej kury i mleka od czarnej krowy. Mają one uchronić Płanetnika przed zapomnieniem i pozwolić mu wrócić na niebo. Poszukując jaja i mleka, bohaterowie (i widzowie) opowieści spotykają inne postacie ze słowiańskiej mitologii - muszą „nie dać się zwieść parszywej Jędzy, stoczyć bój z Bezkostem, a wszystko po to, by uratować Płanetnika, bez którego przestałaby istnieć... nasza pogoda!" (https://teatranimacji.pl/ spektakl/opowiesci-z-niep/). Słabnący i znikający ze sceny Płanetnik może skojarzyć się widzom z umieraniem. To byłoby zgodne z poglądem Ricoeura, że „śmierć oznacza (...) nieobecność w historii”, pozostawanie w tytułowej niepamięci.

Jak widać, czas, pamięć i zapominanie stanowią zasadnicze kwestie poruszane w przedstawieniu. Pozwala to odwołać się do poglądu Ricoeura na temat „nierzeczywistego statusu fikcyjnego doświadczenia czasowego”, zgodnie z którym „postacie nierzeczywiste posiadają nierzeczywiste doświadczenie czasu. (...) czas opowieści 
fikcyjnej jest wolny od uwarunkowań, które wymagają jego ponownego odniesienia do czasu wszechświata” (Ricoeur 2008c: 182). W Opowieściach udaje się Płanetnika uchronić przed zapomnieniem (to fikcyjne doświadczenie czasowe); w rzeczywistości pozascenicznej - Płanetnik i pozostali bohaterowie pogrążyli się w niepamięci.

\section{Słowiańska miłologia}

Spektakl Opowieści z niepamięci powstał na podstawie Bestiariusza stowiańskiego Pawła Zycha i Witolda Vargasa, którzy piszą:

Studiując rodzime baśnie, podania i legendy, odnosimy (...) wrażenie, iż nasi przodkowie kochali niesamowite opowieści. Czy to przy pasterskim ognisku, czy w zadymionej chłopskiej chacie, czy też w modrzewiowym dworku - po zapadnięciu zmroku snuto dziwne i tajemnicze historie (...) Zapraszamy do podróży śladami opowieści naszych przodków, mitów pełnych słowiańskiej magii tak rzadko obecnej we współczesnej polskiej kulturze (Zych, Vargas 2018: 5).

Opowieści wskazane zostają zatem jako element naszej polskiej, słowiańskiej (pre)historii i (pre)tożsamości.

Na początku spektaklu, po zbiorowym odśpiewaniu starosłowiańskiej pieśni, jeden z aktorów - narrator zadaje widowni pytanie: „Znacie tę pieśń? To jedna z wielu tajemniczych i zapomnianych pieśni z dawnych czasów”. Wykonana przez aktorów pieśń, inaczej niż mitologia grecka, jest nieznana współczesnej publiczności, tak samo, jak zawarte w Bestiariuszu historie o „skrzatach, wodnikach i rusałkach”. Mitologia grecka i jej znajomość określa nasze miejsce w kręgu kultury europejskiej. W tej europejskiej kulturze istniejemy jednak także ze swoją słowiańską tradycją, swoim dziedzictwem i - jak pokazuje spektakl - swoją nieznajomością tej spuścizny. Co interesujące, po prasłowiańską mitologię sięgnął nie Słowianin, tylko mieszkający w Holandii Brazylijczyk, Duda Paiva. A przecież pamięć (ale też zapominanie) o swoich kulturowych korzeniach determinuje naszą dzisiejszą tożsamość. Indywidualną i zbiorową.

\section{Opowieść i pojęcia znaczeniowo podobne: mit, legenda, bajka}

Nietrudno zauważyć, że określenie „opowieść” w przypadku omawianego spektaklu uzyskuje podwójne znaczenie. To z jednej strony część tytułu przedstawienia, z drugiej - pewien utwór narracyjny, a więc właśnie prezentujący, opowiadający wydarzenia w jakimś porządku czasowym (Sławiński 1989: 303). Tytułowe Opowieści... to $-\mathrm{z}$ punktu widzenia teorii literatury - dramat, czyli fabularny utwór literacki 
o przeznaczeniu scenicznym, którego źródłem i podstawą stały się zawarte z Bestiariuszu stowiańskim opowieści „o skrzatach, wodnikach i rusałkach”. Z jednej więc strony Opowieści z niepamięci opowieścią nie są, jeśli przez opowieść rozumieć będziemy utwór „o mało wyrazistych założeniach morfologicznych” (Sławiński 1989: 329-330), definiowany jako „narracyjny utwór prozą o objętości przekraczającej rozmiary noweli lub opowiadania, krótszy natomiast od powieści" (Sławiński 1989: 329-330), dla którego charakterystyczna jest jednowątkowa fabuła, chronologiczny układ zdarzeń, luźna budowa, występowanie sytuacji epizodycznych i narratora osobowego (Sławiński 1989: 329-330), z drugiej - z wymienionymi wyżej cechami opowieści (narracyjność i chronologia), mamy też do czynienia w omawianym spektaklu, choć jego literackie źródła odwołują się do innych, podobnych gatunków, takich jak mit, legenda czy bajka. Analizując bajkę magiczną, Władimir Propp wymieniał takie jej cechy, które odnoszą się także do opowieści, stwierdzając nadto, że „za gatunek nadrzędny trzeba uznać opowiadanie i wszelką w ogóle narrację" (Propp 2000: 37). Jeśli zatem „Pieśni się śpiewa, bajki - baje. Nie są one przeznaczone do czytania, lecz do słuchania" (Propp 2000: 76); to opowieści, zgodnie z taką logiką - się opowiada (i słucha). Bo opowieść to też - bardziej potocznie - opowiedziana historia, często dotycząca minionych czasów. Może właśnie ta perspektywa historyczna, odwołująca się do przeszłości, różni w potocznym pojmowaniu „opowieść” od „opowiadania”, które ma konotacje bardziej współczesne. Przedstawiając pochodzenie bajki, Propp pisał: „Bajka nie narodziła się od razu jako gotowy gatunek. Wyrasta ona z mitu, sięgając korzeniami życia obrzędowego i kultowego" (Propp 2000: 77). Za istotę mitów uważał przypisywanie im, jako opowieściom sakralnym, realności wyższego rzędu i znaczenia religijno-magicznego (Propp 2000: 45). Maciej Czeremski pisze:

Propp pokazał, że bajka magiczna stanowi w istocie pochodną charakterystycznych dla tych społeczności [plemiennych - A.S.] wątków mityczno-rytualnych, które (...) są wyrazem swoistego dla nich sposobu postrzegania rzeczywistości. (...) bajki magiczne to relikt dawnych systemów religijnych, zbiór zniekształconych przez upływ czasu „świętych opowieści” związanych z zaginionym sposobem interpretowania rzeczywistości (Czeremski 2011: XXVII-XXVIII).

Interesujące określenie, czym jest opowieść, znajdujemy u Ricoeura: „opowieścią nazywamy dokładnie to, co Arystoteles nazywa mythos, czyli układ zdarzeń" (Ricoeur 2008a: 60). To rozumienie bliskie potocznemu pojmowaniu opowieści, a także odpowiednio objaśniające tytuł poznańskiego spektaklu prezentującego ciąg wydarzeń. Takie właśnie fabularne ujęcie charakterystyczne jest dla form narracyjnych bliskich dzieciom: bajki, legendy, opowieści, za którymi podążają, kierowane ciekawością tego, co wydarzy się dalej. Badania obejmujące konfigurację czasu w opowieści fikcyjnej (baśń, epopeja, tragedia, komedia, powieść [Ricoeur 2008b: 11]) prowadzą do następującej konkluzji: 
Prawo do użycia terminu 'opowieść w znaczeniu rodzajowym - przy pełnym poszanowaniu w stosownych kontekstach różnicy gatunkowej między odmianą diegetyczną i odmianą dramatyczną - opiera się (...) na samym wyborze pojęcia mimesis dziatania jako kategorii kluczowej (...) mythos, od którego wywodzi się nasze pojęcie zawiązania intrygi, jest kategorią o takim samym zakresie, co mimesis akcji. Z tego wyboru wynika, że rozróżnienie między modelem diegetycznym i modelem dramatycznym schodzi na drugi plan (...); dlatego właśnie przykłady dobrze pomyślanej intrygi można zaczerpnąć równie dobrze z Homera, co z Sofoklesa (Ricoeur 2008b: 241-242).

Opierając się na przytoczonych wyżej postulatach Ricoeura, można przyjąć, że Opowieści z niepamięci są właśnie opowieścią z „dobrze pomyślaną” intrygą.

\section{Pamięć, niepamięć, zapominanie i ich społeczne skutki}

Pamięć powszechnie kojarzona jest i łączona raczej z przeszłością niż teraźniejszością czy przyszłością. A jednak Bogusław Milerski pisze o pamięci społecznej, że „nie tylko (...) komunikuje przeszłość. Ona o wiele bardziej jest kluczem do postrzegania przez daną grupę społeczną własnej teraźniejszości i przyszłości” (Milerski 2016: 34-35). Wymienia też trzy aspekty zapamiętywania: 1) społeczne usankcjonowanie i zdeterminowanie tego, co jest zapamiętywane; 2) subiektywne łączenie w pamięci i nadawanie znaczenia poszczególnym zdarzeniom; 3) społeczna ingerencja w tworzenie tych subiektywnych całości, konkludując, że „z takiego ujęcia wynika (...) konieczność krytycznej analizy pamięci jako współczesnego procesu tworzenia znaczących całości - znaczeń, które nadają sens przeszłości oraz (...) teraźniejszości i przyszłości (Milerski 2016: 56). Wydaje się, że tym tropem poszli także twórcy Opowieści z niepamięci, uzależniając przyszłość Ziemi i klimatu od zachowania w pamięci Płanetnika jako elementu przeszłości - prasłowiańskiej mitologii. Takie skierowane ku przyszłości postrzeganie pamięci postuluje też Jacques Le Goff: „Pamięć, z której czerpie zataczająca krąg historia, stara się ocalić przeszłość tylko w służbie teraźniejszości i przyszłości” (Le Goff 2015: 157). Patrząc na Opowieści... z tej przyszłościowej perspektywy, widzimy, że w naszym postrzeganiu realizuje się, jak mówi Ricoeur, „odbijanie się przyszłości na przeszłość w ramach jednego retrospektywnego punktu widzenia historii” (Ricoeur 2006: 508). To, jak postrzegamy swoją słowiańską pratożsamość, zależne jest od naszej dzisiejszej tożsamości, tego, kim jesteśmy (indywidualnie i społecznie) w teraźniejszości. Jak pisze Milerski:

Dziejowość jest (...) czynnikiem warunkującym rozumienie siebie i świata. (...) Pamięć społeczna reinterpretuje przeszłość, a zarazem odnosi się do teraźniejszości i przyszłości. Ona jest warunkiem rozumienia nie tylko tego, co było, ale także tego, co jest i będzie, (...) jest determinowana ideologią danej grupy społecznej dotyczącą sposobów radzenia sobie ze współczesnością i jej pomysłem na własną przyszłość (Milerski 2016: 54-55). 
To prowadzi do zagadnienia zapominania i selektywnego charakteru pamięci nie tylko tego, „co jest pamiętane, ale również (...) co jest zapominane” (Milerski 2016: 57). Prasłowiański Płanetnik coraz bardziej pochłaniany jest przez czarne elementy scenografii - mroki niepamięci. Zapada się w nie coraz głębiej. To wyraźne nawiązanie do wprowadzonej przez Ricoeura idei „głębokości zapomnienia” (Ricouer 2006: 549): „Zapomnienie wprowadza - na płaszczyźnie egzystencjalnej - coś w rodzaju bezkresnej otchłani, którą usiłuje wyrazić metafora wertykalnej głębi" (Ricouer 2006: 549).

Odnosząc się do pamiętania wybiórczego i braku przywiązania do pewnych elementów przeszłości, Ricoeur zwraca uwagę na ważną kwestię dotyczącą wartościującego stosunku do czasu: „idea postępu nie ogranicza się do wskazania apriorycznej wyższości przyszłości (...) nad rzeczy minione. Idea nowości (...) oznacza minimalnie deprecjację wcześniejszego czasu naznaczonego przez przeszłość, a maksymalnie negację sprowadzającą się do zerwania” (Ricouer 2006: 407). Być może ta deprecjacja i zerwanie są powodem, dla którego dzisiejszej widowni zupełnie obce są zarówno pieśni, jak i postaci prezentowane w Opowieściach z niepamięci.

\section{Tożsamośćl i jej kształtowanie ${ }^{2}$}

Le Goff związek pomiędzy pamięcią a tożsamością określa następująco: „Pamięć jest zasadniczym elementem tego, co od niedawna nazywa się tożsamością indywidualną lub zbiorową. Poszukiwanie tożsamości (...) jest jednym z podstawowych działań dzisiejszych jednostek i społeczeństw" (Le Goff 2015: 155). Konsekwentnie stosuje jednak przyszłościowe postrzeganie pamięci i wskazuje także przyszłość jako źródło tożsamości: „Przyszłość, podobnie jak przeszłość, pociąga dzisiejszych ludzi (...) poszukujących własnych korzeni i tożsamości, fascynuje ich bardziej niż kiedykolwiek" (Le Goff 2015: 63). To nie jedyna pozorna sprzeczność, z jaką mamy do czynienia na styku pamięć - kształtowanie tożsamości: także zapominanie jest elementem tożsamości. To, co zachowujemy w pamięci, choć niekoniecznie intencjonalnie, a także to,

\footnotetext{
Jerzy Nikitorowicz następująco definiuje tożsamość: „tożsamość osobowa i społeczno-kulturowa jest wynikiem wolnego i odpowiedzialnego w wyborze samookreślenia jednostki, świadomego przyjęcia zadania kreowania siebie w określonej przestrzeni społeczno-kulturowej, usytuowania siebie w relacjach z innymi ludźmi, określenia hierarchii wartości, zasad i norm postępowania” (Nikitorowicz 2016: 26). Natomiast Barbara Surma wskazuje trzy aspekty związane z kształtowaniem tożsamości kulturowej: 1. Przekaz tradycji i dziedzictwa kulturowego, 2. Podtrzymywanie własnej kultury, kształtowanie systemu wartości, rozumienie siebie, 3. Gotowość do kreowania nowego dorobku kulturowego, nadawanie sensu światu i własnym działaniom (Surma 2016: 75).

2 Zagadnienie kreowania tożsamości kulturowej podejmują m.in. Agnieszka Suchocka i Iwona Królikowska (Suchocka, Królikowska 2014), Jerzy Nikitorowicz (Nikitorowicz 2016), Barbara Surma (Surma 2016) czy Robert John (John 2004).
} 
co z niej (czasem intencjonalnie) usuwamy, wpływa na to, kim jesteśmy jako ludzie i społeczności. Ricoeur zapominanie wiąże też z odpowiedzialnością, pisząc:

(...) jako forma aktywna, zapominanie pociąga za sobą ten sam rodzaj odpowiedzialności, co ta, którą przypisuje się aktom niezwracania uwagi, pomijania, nieostrożności, nieprzezorności, we wszystkich sytuacjach zaniechania działania, gdzie po fakcie pojawia się jasna i uczciwa świadomość, iż powinno się i można wiedzieć (...), że powinno się i można było interweniować (Ricouer 2006: 591).

Może po obejrzeniu Opowieści z niepamięci pojawią się wypowiedziane lub niewypowiedziane pytania, dlaczego słowiańska mitologia - inaczej niż grecka - odeszła w niepamięć i czy czujemy się za to odpowiedzialni. Dlaczego twórcy Teatru Animacji właśnie w drugiej dekadzie XXI wieku po nią sięgnęli? Czy miało to związek z napływem ukraińskich imigrantów - także Słowian, z którymi tę mitologię możemy podzielać, tworząc słowiańską tożsamość?

W roku premiery Opowieści Jerzy Nikitorowicz postulował wprowadzenie w szkołach „programu humanistycznego bloku tematycznego (...) »Nasze dziedzictwo«, którego celem jest nabycie świadomości przeszłości i ukierunkowanie ku przyszłości w ochronie dziedzictwa lokalnego i światowego” (2016: 15). Zachowanie i przekazywanie kulturowego dziedzictwa, emocjonalnie istotnych wartości, symboli i instytucji, wokół których następuje integracja grupy, jest przecież społecznie niezwykle ważne. Mimo tego, różne aspekty i elementy rozmaitych kultur odchodzą w zapomnienie i Opowieści - na konkretnym, rodzimym przykładzie - wyraźnie o tym przypominają. Należy jednak pamiętać, że tendencje te nie we wszystkich kulturach są jednakowo nasilone, a niektóre kultury i grupy szczególnie pielęgnują pamięć o swojej historii i tożsamości. Yosef Hayim Yerushalmi pisał o grupowej pamięci ${ }^{3}$ narodu żydowskiego ${ }^{4}$ : „była funkcją wspólnej wiary, spójności i woli samej grupy, przekazującej i odtwarzającej swoją przeszłość poprzez cały kompleks wzajemnie powiązanych instytucji społecznych i religijnych, które w tym celu organicznie współdziałały" (Yerushalmi 1999: 95).

\footnotetext{
3 Ricoeur zwraca natomiast uwagę na „wewnętrzne zależności miedzy pamięcią indywidualną a pamięcią zbiorową" (Ricouer 2006: 126).

4 Prawidłowość ta dotyczy także innych społeczeństw, choć instytucje transmitujące dziedzictwo kulturowe i pamięć grupową mogą być w nich innego rodzaju. W przypadku Żydów mamy natomiast do czynienia z sytuacją wyjątkową, którą jest ciągłość religijna (w Polsce pojawiło się chrześcijaństwo, które odmitologizowało dawną rzeczywistość). Ponadto w judaizmie pamiętanie, wspominanie, narracja stanowią główny element kształtowania tożsamości i są religijnym imperatywem: „Mojżesz skupił się na tym, jak ważna dla zdrowia moralnego społeczności jest pamięć. (...) W judaizmie (...) stróżem sumienia jest pamięce" (Sack 2019).
} 


\section{Opowieści z niepamięci jako narzędzie w wychowaniu młodych widzów}

Z perspektywy wychowawczej i pedagogiczno-etycznej, poza kwestią pamiętania/ zapominania, będącą osią fabuły spektaklu oraz czynnikiem kształtowania tożsamości widzów, warto zwrócić uwagę na kilka pojawiających się w przedstawieniu postaci', zaczerpniętych z Bestiariusza. Postaci te są pewnego rodzaju nośnikami pamięci, rozumianej jako międzypokoleniowe przekazywanie wartości, i z tego właśnie powodu mają znaczenie w kształtowaniu tożsamości. Ponadto, mimo iż pochodzą z przeszłości, niektóre z nich mają aktualne odniesienia. Można więc przypuszczać, że mitologiczne postaci zostały bardzo celowo dobrane ze względów pedagogiczno-wychowawczych.

Płanetnik - główny mityczny bohater Opowieści - zajmuje się „napełnianiem chmur wodą lub deszczem, przeciąganiem ich na znaczne czasem odległości i opróżnianiem nad danym obszarem" (Zych, Vargas 2018: 114). Historia pradawnego Płanetnika ściągniętego na ziemię i powoli „wymazywanego" z pamięci to zobrazowanie nierozerwalnej łączności między przeszłością, teraźniejszością i przyszłością. Zapomnienie o przeszłości grozi katastrofą (klimatyczną) w przyszłości. To także jasne nawiązanie do działań przeciwko zmianom klimatu.

Jędza, która „w swym ruchomym domku na kurzej stopie przemierzała puszcze w poszukiwaniu ofiar - głównie bezbronnych dzieci (...) w przywabieniu do siebie (...) dziatwy (...) używała skuteczniejszego [niż magia - A.S.] wabika: słodyczy. Znęcone wizją nieograniczonego dostępu do łakoci szkraby łatwo dawały się uwięzić (...) po czym kończyły jako przysmak na stole ohydnego demona” (Zych, Vargas 2018: 96) to kolejna postać, której wymowa jest bardzo aktualna. Tym bardziej, że do udziału w scenach z Jędzą każdorazowo zapraszane jest dziecko z widowni. Współcześnie nadmiar cukru w diecie i coraz częściej dotykająca dzieci nadwaga są bardzo istotnym problemem z pogranicza dietetyki i wychowania. Wskazanie zgubnych skutków apetytu na słodycze jest kwestią pedagogicznie istotną ${ }^{6}$.

\footnotetext{
5 „Postacie występujące w opowieści zostają sfabularyzowane wraz ze zdarzeniami i wraz z nimi tworzą opowiedzianą historię" (Ricoeur 2006: 353).

6 Można oczywiście na postać Jędzy i jej związany z jedzeniem sposób działania spojrzeć z bardzo różnych perspektyw - od psychoanalizy, po koncepcję jedzenia jako elementu święta, karnawału, zabawy. Freudowska faza oralna i jej pozostałości dostrzegane są m.in. w czynności jedzenia: „Jakie pozostałości fazy oralnej można znaleźć u osób dorosłych? (...) znaczący udział w takich zachowaniach związanych z ustami, jak jedzenie i picie (...)" (Erwin 2002: 406). Zaś fiksacja na fazie oralnej w dorosłym życiu prowadzić może np. do nadmiernego objadania się. Natomiast Johan Huizinga w Homo ludens wymienia uczty, przyjęcia i biesiady, a więc aktywności związane ze spożywanie posiłków, jako ważny element święta (Huizinga 1949: 21). Jednak fakt, że Jędza posługuje się konkretnym rodzajem jedzenia - słodyczami, powoduje, że dietetyczny punkt widzenia wydaje się najbardziej zasadny.
} 
Rola Kłobuka, „złego ducha niższego rzędu”, który zabrany przez któregoś z wieśniaków do chaty, zadomawiał się w niej i „zaczynał znosić swoim gospodarzom różne dobra, które kradł innym mieszkańcom wsi” (Zych, Vargas 2018: 104), jest w budowaniu fabuły przedstawienia bardzo ważna. To on jest obwiniany o bycie sprawcą wszelkich kłopotów związanych z Płanetnikiem, które stanowią treść Opowieści: tego, że Płanetnik spadł na ziemię; tego, że jeśli nie wróci na niebo, na ziemi przestanie padać deszcz; tego, że powoli znika w odmętach niepamięci i zapomnienia. Tak naprawdę to człowiek wypowiedział życzenie, to człowiek pozbył się słowiańskich mitów ze swojej pamięci i tożsamości, a Kłobuk był tylko narzędziem.

Z postacią Kłobuka wiążą się dwie kwestie wychowawcze: 1) odpowiedzialności za słowo, która obejmuje też odpowiedzialność za wypowiadane życzenia, oraz 2) odpowiedzialności za zachowania zbiorowe. Kłobuk staje się ofiarą zmasowanego ataku aktorów biorących udział w spektaklu. Niezależnie od tego, czy to on był sprawcą potencjalnego nieszczęścia - zapomnienia Płanetnika, zostaje zaatakowany krzykami „to on”, jest wytykany palcami. Bezbronnie kuli się ze strachu przed atakującym go tłumem. Scena ta może uzmysłowić publiczności strach, jaki odczuwa osoba będąca ofiara tak zwanego „hejtu”.

Baba, „wiekowa kobieta zajmująca się w dawnej polskiej wsi leczeniem i odmawianiem uroków" (Zych, Vargas 2018: 10), jest postacią mniej aktualną, choć to ona zwraca uwagę aktorów na znaczenie pamięci nie tylko dla pamiętających, ale także dla tych, którzy podlegają pamiętaniu lub zapominaniu - z jej ust padają znaczące słowa: „cieszę się, że o mnie pamiętacie”. Po drugie, to ona uświadamia aktorom i widowni zagrożenie związane ze zniknięciem Płanetnika (w przedstawieniu jego znikanie z pamięci obrazuje zapadanie się w rozpadlinę w elemencie scenografii) - brak opadów i katastrofę klimatyczną. Jako stara kobieta ${ }^{8}$ może też funkcjonować w wymiarze

Na scenie widzimy zachowania, które korzeniami sięgają do syndromu kozła ofiarnego - osoby lub grupy, na której członkowie innej grupy rozładowują swoją agresję, obarczając ja odpowiedzialnością za porażki, nieszczęścia, klęski. O takich zachowaniach René Girard pisał w książce poświęconej prześladowaniom: „Mówię tu (...) o prześladowaniach kolektywnych lub też wywołujących kolektywny rezonans. Przez wyrażenie "kolektywne prześladowanie« rozumiem akty gwałtu popełniane bezpośrednio przez zbrodniczy tłum, jak to miało miejsce w przypadku masakry Żydów podczas epidemii dżumy. Przez określenie "prześladowania wywołujące kolektywny rezonans« rozumiem akty przemocy w rodzaju polowań na czarownice (...) zdeterminowane przez podekscytowaną opinię publiczną" (Girard 1987: 21).

8 Nie bez znaczenia wydaje się tu nawiązanie do psychoanalizy C.G. Junga. Baba może być bowiem aktualizacją co najmniej jednego z Jungowskich archetypów - Mądrego starca, który symbolizuje pierwiastek duchowy. „Duch oznacza tutaj sumę wszystkich zjawisk myślenia racjonalnego lub intelektu, łącznie z wolą, pamięcią, wyobraźnią, mocą tworzenia i aspiracjami motywowanymi ideałami (Jung 2010: 86). Zasadne wydaje się też zwrócenie uwagi, że troska, z jaką Baba wyraża się zarówno o zagrożeniu dla przyszłości Ziemi i zamieszkujących ją ludzi, a także zaangażowanie w życzliwe udzielanie rad bohaterom spektaklu, przywołują skojarzenie z innym Jungowskim archetypem - Wielką Matką: „Cechy z nim związane to macierzyńska troska i współczucie; (...) mądrość i duchowe wywyższenie, które wykracza poza rozum; każdy instynkt lub impuls związany z pomocą; (...) wszystko, co pielęgnuje i podtrzymuje (...)” (Jung 2010: 16). 
pedagogicznym jako obowiązujący w przeszłości wzór połączenia starości z mądrością, doświadczeniem i znajomością życia. Warto pamiętać (i przekazywać tę pamięć młodszym widzom), że kiedyś u osób starszych społeczności szukały rady i korzystały z ich życiowej mądrości?.

Poza wspomnianymi postaciami ogromne wychowawczo-etyczne znaczenie ma jedna z ostatnich scen przedstawienia. Gdy Płanetnik niemal został już pochłonięty przez ciemne elementy scenografii - mroki niepamięci i zapomnienia, a uratowanie go - w sytuacji braku jajka od czarnej kury ${ }^{10}$ - wydawało się prawie niemożliwe, jeden z aktorów oddaje swoją bezwłosą głowę jako jajko chwilę wcześniej zniesione przez $\mathrm{Kłobuka}^{11}$. W ten sposób, poświęcając się, doprowadza do szczęśliwego zakończenia opowiadanej historii - ratuje zbiorową pamięć scenicznej społeczności, ratuje Płanetnika od zapomnienia, a Ziemię od suszy. W następnej scenie z teatralnego nieba, na które powrócił Płanetnik, pada śnieg. Może być to przykład pewnego rodzaju poświęcenia dla dobra wspólnego ${ }^{12}$ - jednej z najważniejszych współcześnie wartości nie tylko na gruncie prawodawstwa, ale także filozofii i pedagogiki.

$\mathrm{Na}$ etyczny wymiar samej opowieści zwraca zaś uwagę Ricoeur pisząc:

(...) strategia perswazji stosowana przez narratora dąży do narzucenia czytelnikowi pewnej wizji świata, która nigdy nie jest neutralna etycznie, a raczej skłania (...) do nowego sposobu oceniania świata oraz samego czytelnika (...) opowieść należy już do pola etycznego na mocy roszczenia - właściwego każdej narracji - do etycznej słuszności (Ricoeur 2008c: 357).

Każde przedstawienie teatralne mieści się w obszarze pedagogiki kultury, której celem jest „kształtowanie osobowości w oparciu o dobra kultury” (Milerski, Śliwerski 2000: 153), i jest narzędziem wychowania aksjologicznego. Kształcenie poprzez dobra i teksty kultury

(...) staje się kluczem do rozumienia przez człowieka własnego bytu. W tym sensie ma ono [kształcenie humanistyczne - A.S.] również wymiar egzystencjalny. Co więcej, jeżeli uczącego się łączy z tekstami kulturowymi relacja rozumienia hermeneutycznego, wtedy nie tylko uczy się rozumieć teksty i siebie samego, lecz również uwewnętrznia

\footnotetext{
9. Współcześnie młodzi ludzie nie doceniają doświadczenia życiowego seniorów, rzadko ich słuchają i nie cenią, a „rosnąca liczba ludzi w podeszłym wieku zaczyna być traktowana jako masa staruszków, a nie elita starców" (Erikson 2002: 9).

10 „Bywało że (...) Płanetnik spadał na ziemię. Zachodził wtedy do wieśniaków, prosząc o mleko od czarnej krowy i jaja od czarnej kury. Posiliwszy się (...) unosił się do nieba” (Zych, Vargas 2018: 114).

11 Kłobuk „przybierał (...) postać czarnego, podobnego do kurczaka ptaszyska (Zych, Vargas 2018: 104).

12 Indywidualne poświęcenie dla zbiorowości obecne jest jako wartość w wielu kulturach - nie tylko chrześcijańskiej, o czym dobitnie świadczy m.in. starożytny mit o Prometeuszu. O idei dobra wspólnego można przeczytać m.in. w: A. Młynarska-Sobaczewska (2009) czy M. Piechowiak (2003).
} 
we własnej osobowości sensy i wartości, których nośnikami są teksty. I to właśnie jest istotą kształcenia humanistycznego, a mianowicie kształtowanie kulturowej struktury osobowości jako struktury sensów i wartości (Milerski 2016: 41).

\section{Zakończenie}

Twórcy przedstawienia piszą:

O wierzeniach i praktykach dawnych Słowian wiemy niewiele. Dawne posągi i świątynie zostały spalone, a pogańskie wierzenia skutecznie zastąpiono chrześcijańskimi. Do dzisiejszych czasów przetrwał niewielki okruszek kulturalnego bogactwa naszych słowiańskich przodków. Tworząc spektakl Opowieści z niepamięci chcielibyśmy ocalić od zapomnienia cień świata, który bezpowrotnie przeminął” (https://teatranimacji.pl/ edukacja-nauczyciele/, dostęp: 15.02.2020).

Warto zauważyć, że to ciekawe przywołanie czasów przedchrześcijańskich ma miejsce w mieście, które szczyci się Złotą Kaplicą, miejscem pochówku Mieszka I - władcy, który przyjął chrzest i wprowadził Polskę w świat chrześcijaństwa i jego kultury. Pamięć o tym, że w czasach przedchrześcijańskich słowiańskie plemiona też miały swoją kulturę i religię, że nie były to czasy „dzikie”, że warto o tych czasach pamiętać i nie wykreślać ich z obszaru własnej tożsamości, to jeden z pedagogicznie ważnych tematów.

Pedagogiczne oddziaływania Opowieści mogą okazać się trudne, ponieważ: „być może (...) jesteśmy świadkami - a także sprawcami - jakiegoś rodzaju śmierci, śmierci sztuki bajania (...), skąd wywodzi się sztuka opowiadania (...) w każdej swojej postaci” (Ricoeur 2008b: 50-51). „Śmierć opowiadania” nie pozostałaby naturalnie bez wpływu na naszą tożsamość i dlatego „być może należy wbrew wszystkiemu (...) wierzyć, że nowe formy narracyjne (...) które właśnie się rodzą, poświadczą, że funkcja narracyjna może się zmieniać, lecz nie umrzeć. Nie mamy bowiem żadnej idei tego, czym byłaby kultura, w której by już nie wiedziano, co znaczy opowiadanie (...)" (Ricoeur 2008b: 50-51). Konstatacja Ricoeura może natomiast oznaczać, że z pamięci, świadomości i tożsamości zbiorowej współczesnych ludzi usuwane są nie tylko zaprezentowane w spektaklu pradawne mity, ale także przekazujące je, istotne z punktu widzenia wychowania oraz kształtowania tożsamości, formy narracyjne. Wskazując znaczące miejsce pamięci w działaniach pedagogicznych i edukacyjnych, Milerski pisze:

Kształcenie humanistyczne to nie tylko kształtowanie osobowości kulturowej, samodzielnego osądu, odpowiedzialności i kompetencji komunikacyjnych. To również kształtowanie odczytywania świata w jego wieloznaczności i ideologicznych uwarunkowaniach. (...) Warunkiem realizacji tak zdefiniowanych celów jest uwzględnienie w teorii kształcenia kategorii pamięci społecznej jako czynnika warunkującego jednostkową i społeczną świadomość (Milerski 2016: 45-46). 
Ricoeur postrzega pamięć w kontekście obowiązku i długu: „obowiązek pamiętania jest obowiązkiem oddawania sprawiedliwości komuś innemu niż sobie samemu poprzez wspomnienie" (Ricouer 2006: 117). Obowiązek pamiętania wiąże się z pojęciem długu - ,jesteśmy dłużni wobec tych, którzy nas poprzedzali w tym czym jesteśmy" (Ricouer 2006: 117) - w naszej, a także ich, naszych przodków, tożsamości. W przypadku Opowieści z niepamięci możemy wyraźnie odczuć nasz dług wobec prasłowiańskiej kultury - dziś, jako społeczność czy społeczeństwo, bylibyśmy kimś innym, gdyby to nie ona poprzedzała nasze słowiańskie chrześcijaństwo, które schrystianizowało znaczną część pogańskich tradycji. Przypominanie o tym jest chyba główną rolą opowieści i Opowieści.

\section{Bibliografia}

Cukras-Stelągowska J. (2016). Stowo wstępne, [w:] J. Cukras-Stelągowska (red.), Pamiętanie i zapominanie. Wspólnoty - wartości - wychowanie, Toruń: Wydawnictwo Naukowe Uniwersytetu Mikołaja Kopernika.

Czeremski M. (2011). Oswojenie bajki. Morfologia Wtadimira Proppa, [w:] W. Propp, Morfologia bajki magicznej, Kraków: Nomos.

Erikson E. H. (2002). Dopetniony cykl życia, tłum. A. Gomola, Poznań: Rebis.

Erwin E. (red). (2002). The Freud Encyclopedia. Theory, Therapy, and Culture. New York \& London: Routledge.

Girard R. (1987). Koziot ofiarny, tłum. M. Goszczyńska, Łódź: Wydawnictwo Łódzkie.

Hiuzinga J. (1949). Homo Ludens. A Study of the Play-Element in Culture, London, Boston and Henley: Routledge \& Kegan.

John R. (2004). Problem uznania w procesie ksztattowania wspótczesnej tożsamości, „Dialogi Polityczne. Polityka - Filozofia - Społeczeństwo - Prawo: Polityczność nad Sekwaną", nr 3-4, s. 193-197.

Jung C. G. (2010). Four Archetypes. From Vol. 9, Part 1 of the Collected Works of C. G. Jung, Princeton, NJ: Princeton University Press.

Le Goff J. (2015). Historia i pamięć, tłum. A. Gronowska, J. Stryjczyk, Warszawa: Wydawnictwo Uniwersytetu Warszawskiego.

Milerski B. (2016). Pamięć jako element ksztatcenia humanistycznego, [w:] J. Cukras-Stelągowska (red.), Pamiętanie i zapominanie. Wspólnoty - wartości-wychowanie, Toruń: Wydawnictwo Naukowe Uniwersytetu Mikołaja Kopernika.

Milerski B., Śliwerski B. (red). (2000). Leksykon PWN. Pedagogika, Warszawa: Wydawnictwo Naukowe PWN.

Młynarska-Sobaczewska A. (2009). Dobro wspólne jako kategoria normatywna, „Acta Universitatis Lodziensis. Folia Juridica", Vol. 69, s. 61-72.

Nikitorowicz J. (2016). Wartość dziedzictwa kulturowego w procesie ustawicznego ksztattowania się tożsamości, [w:] J. Cukras-Stelągowska (red.), Pamiętanie i zapominanie. Wspólnoty - wartości - wychowanie, Toruń: Wydawnictwo Naukowe Uniwersytetu Mikołaja Kopernika. 
Piechowiak M. (2003). Filozoficzne podstawy rozumienia dobra wspólnego, „Kwartalnik Filozoficzny", T. XXXI, Z. 2, s. 5-35.

Propp W. (2000). Nie tylko bajka, tłum. D. Ulicka, Warszawa: Wydawnictwo Naukowe PWN.

Ricoeur P. (2008a). Czas i opowieść. Tom 1. Intryga i historyczna opowieść, tłum. M. Frankiewicz, Kraków: Wydawnictwo Uniwersytetu Jagiellońskiego.

Ricoeur P. (2008b). Czas i opowieść. Tom 2. Konfiguracja w opowieści fikcyjnej, tłum. J. Jakubowski, Kraków: Wydawnictwo Uniwersytetu Jagiellońskiego.

Ricoeur P. (2008c). Czas i opowieść. Tom 3. Czas opowiadany, tłum. U. Zbrzeźniak, Kraków: Wydawnictwo Uniwersytetu Jagiellońskiego.

Ricoeur P. (2006). Pamięć, historia, zapomnienie, tłum. J. Margański, Kraków: Universitas. Sacks J. (2019). Polityka pamięci [komentarz do parszy Ekew], <https://chidusz.com/ komentarze-biblia-tora-talmud-stary-testament-rabin-jonathan-sacks-parsza-parasza-paraszat-eikev-ekew-zydzi-judaizm-kazanie-5779-szabat-pamiec-solidarnosc-cywilizacja/> (dostęp: 29.03.2020).

Sławiński J. (red). (1989). Stownik terminów literackich, Wrocław: Zakład Narodowy im. Ossolińskich.

Suchocka A., Królikowska I. (2014). Kreowanie tożsamości kulturowej jako wyzwanie XXI wieku, „Colloquium. Kwartalnik”, Nr 4, s. 73-88.

Surma B. (2016). Pamięć i narracja $w$ ksztattowaniu tożsamości kulturowej $w$ pedagogice Marii Montessori, [w:] J. Cukras-Stelągowska (red.), Pamiętanie i zapominanie. Wspólnoty - wartości - wychowanie, Toruń: Wydawnictwo Naukowe Uniwersytetu Mikołaja Kopernika.

Zych P., Vargas W. (2018). Bestiariusz stowiański. Rzecz o skrzatach, wodnikach i rusatkach, Olszanica: Bosz.

Yerushalmi Y.H. (1999). Zakhor, Jewish History and Jewish Memory, Seattle: University of Washington Press.

Netografia:

https://teatranimacji.pl/edukacja-nauczyciele/ (dostęp: 15.02.2020).

https://teatranimacji.pl/spektakl/opowiesci-z-niep/ (dostęp: 06.02.2020).

\section{ADRES DO KORESPONDENCJI}

Anna Sanecka

Dolnośląska Szkoła Wyższa

anna.sanecka@gmail.com 